\title{
neonatal medicine
}

\section{A Case of Spontaneous Twin Anemia-Polycythemia Sequence}

Kwan Dae Myung, M.D., Yeon Kyung Lee, M.D., Sun Young Ko, M.D., Son Moon Shin, M.D., Jin Hoon Chung, M.D.*, and Sung Ran Hong, M.D. ${ }^{\dagger}$

Departments of Pediatrics, Obsterics and Gynecology*, Pathology ${ }^{\dagger}$, Cheil General Hospital \& Women's Health Care Center, Dankook University College of Medicine, Seoul, Korea

\section{ABSTRACT}

Twin anemia-polycythemia sequence (TAPS) is characterized by the transfer of blood via intertwin vascular anastomoses in a single placenta. It differs from twin-twin transfusion syndrome (TTTS) in that amniotic fluid levels remain normal during pregnancy. Since the concept of TAPS was first introduced in 2007, some cases have been reported abroad, but no such a case has been reported in Korea. Here, we report the first case of spontaneous TAPS in Korea.

Key Words: TAPS, Twin anemia-polycythemia sequence, TTTS, Twin-twin transfusion syndrome

\section{서론}

단일 융모막 쌍태아는 하나의 태반으로 태아-모체간 순환을 공유하는 것이 특징이다. 이러 한 쌍태아에서 태반에서의 비정상적인 혈관 문합을 통한 혈액의 불균형적인 이동은 쌍태아간 수혈 증후군(twin-twin transfusion syndrome, TTTS)과 쌍태아 빈혈-적혈구증가증 현상 (twin anemia-polycythemia sequence, TAPS)같은 합병증을 일으킬 수 있다. TTTS는 쌍태 아간의 양수량의 차이를 특징으로 하는 반면, TAPS는 쌍태아간의 양수량의 차이는 없으면 서 혈색소의 차이를 보이는 질환으로 2007년에 개념이 도입된 이후 국외에서의 연구는 있으 나, 국내에서는 현재까지 보고된 바가 없다 ${ }^{1}$. 저자들은 spontaneous TAPS 환자 1례를 경험 하였기에 문헌 고찰과 함께 보고하는 바이다.

\section{증례}

환자: 김OO 아기 1 (본 증례의 첫째 남아), 김OO 아기2 (본 증례의 둘째 남아)

\section{주소: 호흡곤란}

출생력 및 현병력: 산모의 조기진통 및 조기양막파수로 인해 재태 주수 36 주 6일에 첫째는 $3,020 \mathrm{~g}$ 으로 출생하여 아프가 점수 1분에 6점, 5분에 7점이었고, 둘째는 2,860 g으로 아프가
Received: 16 March 2016

Revised: 16 June 2016

Accepted: 20 June 2016

Correspondence to: Yeon Kyung Lee Department of Pediatrics, Cheil General Hospital and Women's Healthcare Center, Dankook University College of Medicine, 17 Seoae-ro 1-gil, Jung-gu, Seoul 04619, Korea

Tel: +82-2-2000-7771

Fax: +82-2-2000-7778

E-mail: ykleeped@hanmail.net

Copyright(c)

By Korean Society of Neonatology.

All right reserved.

This is an Open-Access article distributed under the terms of the Creative Commons Attribution Non-Commercial License (http://creativecommons.org/licenses/ by-nc/4.0), which permits unrestricted non-commercial use, distribution, and reproduction in any medium, provided the original work is properly cited. 
점수 1분에 4점, 5 분에 6점으로 제왕절개를 통해 출생하였다. 두 환자 모두 빈호흡, 흥부 견축 등의 호흡곤란 증상을 보여 기관 삽 관 후 기계적 환기 치료를 시행하였다.

분만력 및 가족력: 산모는 35세 경산모로 산과력은 3-2-0-2이 었고, 자연 쌍태임신으로 산전 초음파에서 단일 융모막 이양막 이 외에 특이 소견은 없었으며, 쌍태아간의 양수양의 차이는 보이지 않았다.

이학적 소견 및 검사 소견: 첫째 환자의 입원 당시 활력 징후 는 맥박 165 회/분, 혈압 $71 / 43 \mathrm{mmHg}$, 호흡수 72 회/분, 체온은 $36.5^{\circ} \mathrm{C}$ 였다. 몸무게 $3,020 \mathrm{~g}\left(50-75^{\text {th }}\right.$ percentile), 신장 $46 \mathrm{~cm}$ $\left(25-50^{\text {th }}\right.$ percentile), 두위 $34 \mathrm{~cm}\left(75-90^{\text {th }}\right.$ percentile) 였으며, 붉은 피부색을 보였다(Figure 1A). 출생 당시 말초혈액의 혈색소 치는 $25.3 \mathrm{~g} / \mathrm{dL}$, 적혈구용적률 $75.3 \%$ 로 적혈구증가증을 보였고 (Table 1), 백혈구는 $12,910 / \mu \mathrm{L}$, 혈소판은 $164,000 / \mu \mathrm{L}$ 이었다. 진찰 소견상 빈호흡, 흥부 견축이 관찰되었고, 심음은 규칙적이었으며, 심잡음은 들리지 않았다.

둘째 환자는 입원 당시 맥박 140 회/분, 혈압 $48 / 23 \mathrm{mmHg}$, 호 흡수 64 회/분, 체온은 $36.7^{\circ} \mathrm{C}$ 였다. 몸무게 $2,860 \mathrm{~g}\left(50-75^{\text {th }}\right.$ percentile), 신장 $48 \mathrm{~cm}\left(50-75^{\text {th }}\right.$ percentile), 두위 $32.7 \mathrm{~cm}\left(25-50^{\text {th }}\right.$ percentile) 였으며, 피부색은 창백하였으나 태아수종의 소견은 없었다(Figure 1B). 출생 당시 말초혈액의 혈색소치는 $9.8 \mathrm{~g} / \mathrm{dL}$, 적혈구용적률 30.1\%로 빈혈을 보였고(Table 1), 백혈구는 15,340/ $\mu \mathrm{L}$, 혈소판은 $104,000 / \mu \mathrm{L}$ 이었다. 진찰 소견상 빈호흡과 흥부 견축 이 관찰되었고, 심음은 규칙적이었으며, 심잡음은 들리지 않았다.

태반 조직검사: 매우 가는 동맥 대 동맥의 태반 혈관 문합이 있
었다(Figure 2).

치료 및 임상 경과: 첫째 환자는 출생 후 바로 기관 삽관을 하고 기계적 환기 치료를 시행하였고, 제대정맥도관을 삽입하고 부분교 환 수혈을 2 회 시행하였다. 이후 생후 3 일째 말초혈액의 혈색소치 는 $20.3 \mathrm{~g} / \mathrm{dL}$, 적혈구용적률 59.3\%, 망상적혈구 $4.9 \%$ 이었고, 말 초혈액 도말검사에서 정적혈구성 정색소성 적혈구(normocytic normochromic RBC)가 관찰되었으며, 일반 생화학 검사, 혈청 전 해질 검사에서 이상 소견은 없었다. 생후 2 일째 자발 호흡이 원활 하여 기도 발관을 하였으며, 생후 4 일째부터 경구 수유를 시작하 였다. 간헐적인 고혈압 있어 7일째 심초음파 검사 및 신장 초음파 검사를 시행하였으나 정상이었고, 약물 치료없이 호전되어 14일째 퇴원하였다. 환자는 현재 별다른 문제없이 건강하게 잘 자라고 있 다.

둘째 환자는 출생 후 바로 기관 삽관 및 기계적 환기 치료를 하 였고, 제대정맥도관 삽입하고 농축 적혈구 수혈 $(15 \mathrm{cc} / \mathrm{kg})$ 을 시 행하였다. 이때 시행한 말초혈액 도말검사에서 구상 적혈구증을 동반한 정적혈구성 정색소성 빈혈(normocytic normochromic anemia with spherocytosis)이 관찰되었다. 생후 3일째 말초혈액 의 혈색소치는 $18.4 \mathrm{~g} / \mathrm{dL}$, 적혈구용적률 $53.0 \%$ 으로 상승되었으 며, 생후 6 일째 혈소판 $29,000 / \mu \mathrm{L}$ 으로 혈소판 감소증이 보여 혈소 판 농축액을 수혈하였고, 이후 정상 혈소판 수를 유지하였다. 생후 2일째 자발 호흡이 원활하여 기도 발관을 하였으나, 빈호흡과 흥 부 견축으로 지속적 상기도 양압기(continuous positive airway pressure, $\mathrm{CPAP}$ ) 치료를 하였으며, 이후 호흡 증상 점차 호전되 어 생후 8일째 $\mathrm{CPAP}$ 을 제거하였다. 생후 4일째부터 경구 수유를

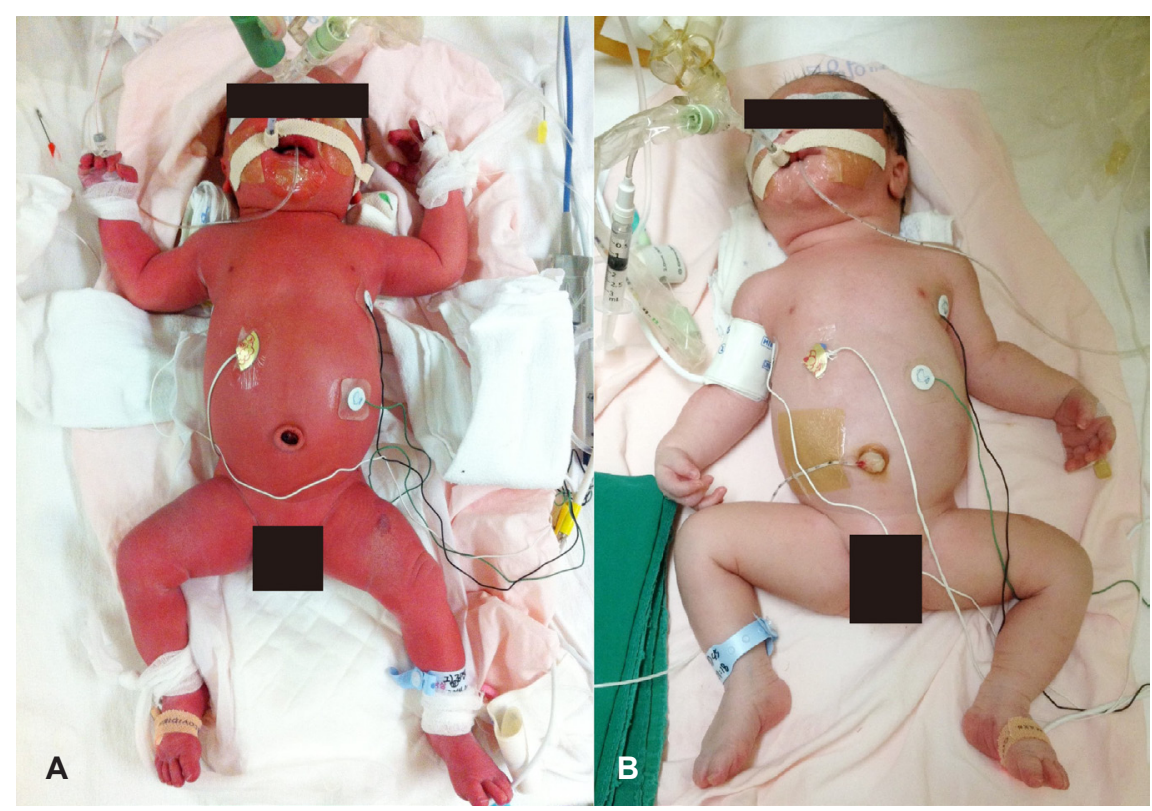

Figure 1. Spontaneous twin anemia-polycythemia sequence at birth: a plethoric polycythemic recipient (A) and a pale anemic donor (B). 
Table 1. Clinical Summary of Twin Anemia-Polycythemia Sequence Patients

\begin{tabular}{|c|c|c|}
\hline & Baby 1 & Baby 2 \\
\hline \multicolumn{3}{|l|}{ Antenatal sonogram } \\
\hline \multicolumn{3}{|c|}{ Amniotic fluid : Single pocket $(\mathrm{cm})$} \\
\hline IUP 32 weeks & 5.0 & 3.9 \\
\hline IUP $33^{+6}$ weeks & 5.9 & 4.0 \\
\hline IUP $35^{+6}$ weeks & 3.8 & 3.1 \\
\hline Gestational age (wks) & \multicolumn{2}{|c|}{$36^{+6}$} \\
\hline Placenta type & \multicolumn{2}{|c|}{ Monochorionic diamniotic } \\
\hline Delivery mode & \multicolumn{2}{|c|}{ Cesarean section } \\
\hline \multicolumn{3}{|l|}{ Body profile } \\
\hline Birth weight (g) & $3,020\left(50-75^{\text {th }}\right.$ percentile $)$ & $2,860\left(50-75^{\text {th }}\right.$ percentile $)$ \\
\hline Head circumference $(\mathrm{cm})$ & $34\left(75-90^{\text {th }}\right.$ percentile $)$ & $32.7\left(25-50^{\text {th }}\right.$ percentile $)$ \\
\hline Height $(\mathrm{cm})$ & $46\left(25-50^{\text {th }}\right.$ percentile $)$ & $48\left(50-75^{\text {th }}\right.$ percentile $)$ \\
\hline Apgar score (1 min/5 min) & $6 / 7$ & $4 / 6$ \\
\hline $\mathrm{Hb}(\mathrm{g} / \mathrm{dL})$ & 25.3 & 9.8 \\
\hline Hct (\%) & 75.3 & 30.1 \\
\hline Reticulocyte (\%) & 4.9 & 6.3 \\
\hline Management & Partial exchange & $\mathrm{p}-\mathrm{RBC}$ transfusion \\
\hline
\end{tabular}

Abbreviations: IUP, intrauterine period; Hb, hemoglobin; Hct, hematocrit; p-RBC, packed red blood cell.

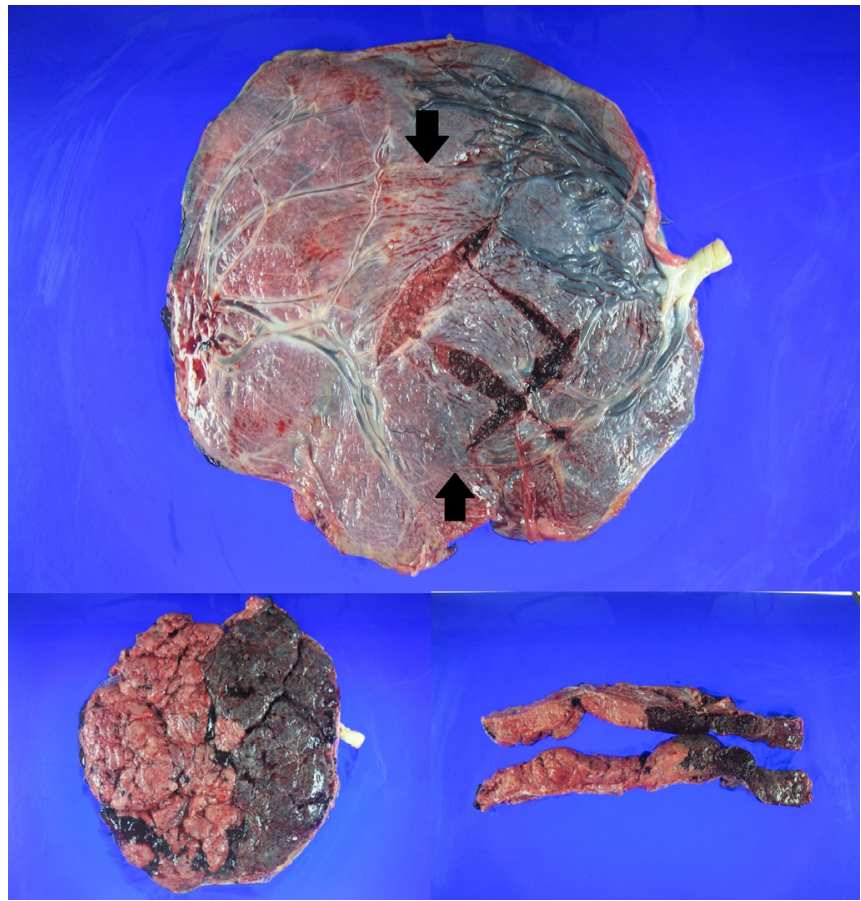

Figure 2. Placental examination in a spontaneous twin anemia polycythemia sequence: the arrows indicate arterioarterial anastomoses.

시작하였고, 첫째 아기와 마찬가지로 간헐적인 고혈압이 있어 7 일째 심초음파 검사 및 신장 초음파 검사를 시행하였으나 정상이 었고, 약물 치료없이 점차 호전되었다. 생후 3일째부터 AST/ALT
428/268 IU/L, direct bilirubin $1.5 \mathrm{mg} / \mathrm{dL}$ 로 증가하였고, AST/ $\mathrm{ALT}$ 는 추적 검사에서 점차 감소하였으나, direct bilirubin의 증가 로 복부 초음파를 시행하였고 특이 소견은 없었다. 선천성 대사이 상 검사, 뇌 초음파검사 및 청성 뇌간 반응검사는 모두 정상이었으 며 21일째 퇴원하였다. 이후 외래에서 경과 관찰하면서 AST/ALT 및 direct bilirubin은 정상으로 회복되었고, 현재 별다른 문제 없 이 정상적인 성장과 발달을 보이고 있다.

\section{고찰}

단일 융모막 쌍태아는 하나의 태반으로 태아-모체간 순환을 공 유하는 특징이 있다. 이러한 쌍태아에서 공유하고 있는 태반에서 의 비정상적인 혈관 문합을 통한 혈류의 불균형으로 여러 가지 합 병증이 나타날 수 있는데 그 중 쌍태아간 수혈 증후군(twin-twin transfusion syndrome, TTTS)과 쌍태아 빈혈-적혈구증가증 현 상(twin anemia-polycythemia sequence, TAPS)이 대표적이다. Shartz ${ }^{2}$ 는 “3번째 순환"(the third circulation)으로 단일 융모막 쌍태아간의 태반 혈관 문합을 처음으로 기술하였고 이러한 혈관 문합은 쌍태아에게 영향을 준다. TTTS는 아직까지 병인이 정확하 게 밝혀져 있지 않으나 쌍태아간의 태반혈관문합, 태아의 체액, 생 화학적, 혈류역학적 변화 등의 복합적인 병태생리를 보이는 질환이 다. 공혈아에서 수혈아 측으로 혈액 공급이 계속되는 경우, 공혈아 는 빈혈, 저혈압, 소변양 감소, 자궁내 태아발육부전, 양수 과소증 
을 초래하고, 수혈아는 다혈, 고혈압, 소변양 증가, 양수 과다증을 동반하게 되어 진행시에는 태아 수종이 발생한다. 쌍태아간 수혈 증후군의 진단은 단일 융모막 태반을 가진 쌍태아에서 초음파상 작은 태아와 큰 태아 사이에서 각각 양수과소증과 양수과다증을 보이는 경우로, 작은 태아의 양수의 최대 수직 깊이가 $2 \mathrm{~cm}$ 이하, 큰 태아에서는 $8 \mathrm{~cm}$ 이상으로 정의 한다 ${ }^{3)}$.

TTTS와는 다르게 TAPS는 양수량의 차이없이 만성적인 태아 간 수혈로 인해 혈색소의 차이만 보이는 것이 특징으로, 2007년에 처음으로 개념이 도입되었다 ${ }^{1)}$ TAPS는 크게 자연적으로 발생하는 경우와 TTTS의 laser 수술 이후에 발생하는 경우로 나눌 수가 있 다. 자연적으로 발생하는 경우는 단일 융모막 쌍태아의 약 3-6\% 에서 발견되며 ${ }^{4)}$, TTTS laser 수술 후 발생하는 경우에는 TTTS의 약 2-14\%에서 발견된다고 알려져 있다 ${ }^{5-7)}$.

TAPS에서 태반의 혈관 문합은 보통 아주 작은 동정맥 문합 (arteriovenous anastomosis)을 통해 이루어진다 ${ }^{8)}$. 이러한 문합 을 통해 공혈아와 수혈아간에 천천히 수혈이 이루어져 결국 큰 혈 색소치 차이를 보이는 것이 특징이다. 드물지만 동맥대 동맥문합 (arterioarterial anastomosis)으로 인한 TAPS도 보고되고 있으 며,10), 본 증례의 태반 혈관 문합은 동맥대 동맥을 통해 이루어졌 다.

진단은 산전에 진단하는 방법과 출생 후에 진단하는 방법으로 크게 두 가지로 나눌 수 있다. 산전에는 초음파에서 공혈아와 수 혈아의 중대뇌동맥(middle cerebral artery, MCA)의 최대 수축기 속도(peak systolic velocity, PSV)를 이용한다. 공혈아의 MCAPSV가 1.5 multiples of the media (MoM)을 초과하고, 수혈아의 MCA-PSV가 $1.0 \mathrm{MoM}$ 미만일 때로 진단할 수 있다. 출생 후 진단 하는 방법은 공혈아와 수혈아의 혈색소 차이가 $8.0 \mathrm{~g} / \mathrm{dL}$ 를 초과 하면서, 망상적혈구비가 1.7 을 초과하거나, 태반에 직경 $1 \mathrm{~mm}$ 이 하의 작은 혈관 문합이 관찰되는 것 중 적어도 하나를 만족하면 된다 ${ }^{11}$. 또한 쌍태아 간의 빈혈과 적혈구증가증의 정도를 반영하 고, 치료 결과 비교를 표준화하는데 도움을 주도록 병기(stage)를 설정하는데, 병기 설정방법으로는 출생 전에 초음파를 통해 공혈 아와 수혈아의 MCA-PSV 차이로 분류하는 방법과 출생 후에 쌍 태아 간의 혈색소 차이를 기준으로 하는 방법이 있다. 출생 전 병 기설정은 공혈아 MCA-PSV >1.5 MoM 이고, 수혈아 MCA-PSV $<1.0 \mathrm{MoM}$ 이면 stage 1, 공혈아 MCA-PSV >1.7 MoM 이고, 수혈 아 MCA-PSV $<0.8 \mathrm{MoM}$ 이면 stage 2, stage 1 또는 stage 2에 서 공혈아의 제대 동맥과 제대 정맥을 통한 비정상적 혈류로 심장 의 문제가 동반된 경우 stage 3, 공혈아가 태아 수종이 있는 경우 stage 4, TAPS로 인해 쌍태아 중 한 명 또는 둘 다 자궁내 태아사 망인 경우 stage 5 로 정의하였다. 출생 후 병기설정은 쌍태아 간의 혈색소 차이가 $8.0 \mathrm{~g} / \mathrm{dL}$ 초과시 stage $1,11.0 \mathrm{~g} / \mathrm{dL}$ 초과시 stage 2, $14.0 \mathrm{~g} / \mathrm{dL}$ 초과시 stage 3, $17.0 \mathrm{~g} / \mathrm{dL}$ 초과시 stage $4,20.0 \mathrm{~g} / \mathrm{dL}$
초과시 stage 5 로 정의하였다 ${ }^{12)}$. 본 증례에서는 산전 초음파에서 MCA-PSV는 측정하지 못하였으나, 출생 후 쌍태아 간의 혈색소 차이는 $15.5 \mathrm{~g} / \mathrm{dL}$ 로 $8.0 \mathrm{~g} / \mathrm{dL}$ 을 초과 하였고, 망상적혈구비는 1.3 이었으나 태반의 직경 $1 \mathrm{~mm}$ 이하의 동맥대 동맥문합이 관찰되어 stage 3의 TAPS로 진단하였다.

MCA-PSV 측정을 통해 이루어지는 비침습적인 도플러 초음 파검사는 산전 태아 빈혈 및 태아 수종의 조기 진단에 있어서 중 요한 역할을 한다 ${ }^{13)}$. 산전에 양수양의 차이에 의해서 구분되는 TTTS와 달리, 본 증례와 같은 TAPS에서는 MCA 도플러의 측정 만이 유용한 진단 방법이다 ${ }^{12}$. 따라서 단일 융모막 쌍태아의 산전 초음파 검사에서 $\mathrm{MCA}$ 도플러의 측정을 기본적으로 시행하는 것 이 도움이 될 것으로 생각되며, 최근의 국제 산부인과 초음파학회 에서도 단일 융모막 쌍태아에서의 TAPS를 선별하기 위하여 임신 20주부터 MCA-PSV의 측정을 권장하고 있다 ${ }^{14)}$.

주산기적 치료로는 기대요법, 유도분만, 자궁내 수혈, 선택적 유 산술, 태아경 레이져 광응고술 등이 시도되나 최적의 치료법을 결 정하기에는 아직 더 많은 연구가 필요하다 ${ }^{12,15)}$. 신생아기의 이환율 은 보통 출생 당시 혈액 질환의 문제에 국한된 경우가 많고, 공혈아 의 경우 심한 빈혈로 수혈을 하는 반면, 수혈아의 경우 심한 적혈 구증가증으로 부분 교환 수혈을 할 수도 있다.

장기간 신경학적 발달의 예후는 아직까지 잘 알려져 있지 않으 나, laser 치료를 한 TTTS 환자의 장기적 예후를 분석한 연구 중 에서 TAPS 6쌍의 예후를 관찰할 수 있었고, 모두 정상적인 신경학 적 발달을 보였다 ${ }^{16)}$. 장기간 예후를 알기 위해서는 보다 많은 연구 가 필요할 것으로 생각된다.

저자들은 국외에서의 연구와 보고는 있으나, 국내에서는 아직 보고된 바 없는 spontaneous TAPS 환자 1례를 경험하였기에 문 헌 고찰과 함께 보고하는 바이다.

\section{REFERENCES}

1) Lopriore E, Middeldorp JM, Oepkes D, Kanhai HH, Walther FJ, Vandenbussche FP. Twin anemia-polycythemia sequence in two monochorionic twin pairs without oligopolyhydramnios sequence. Placenta 2007;28:47-51.

2) Schartz F. Eine besondere art von einseitiger polyhydramnie mit anderseiter oligohydramnie bei eineiiger zwillingen. Arch Gynakol 1882;19:329-69.

3) Brennan JN, Diwan RV, Rosen MG, Bellon EM. Fetofetal tansfusion syndrome: prenatal ultrasonographic diagnosis. Radiology 1982;143:535-6.

4) Lewi L, Jani J, Blickstein I, Huber A, Gucciardo L, Van Mieghem $\mathrm{T}$, et al. The outcome of monochorionic diamniotic twin 
gestations in the era of invasive fetal therapy: a prospective cohort study. Am J Obstet Gynecol 2008;199:514.e1-8.

5) Lopriore E, Slaghekke F, Middeldorp JM, Klumper FJ, Oepkes D, Vandenbussche FP. Residual anastomoses in twin-to-twin transfusion syndrome treated with selective fetoscopic laser surgery: localization, size, and consequences. Am J Obstet Gynecol 2009;201:66.e1-4.

6) Robyr R, Lewi L, Salomon LJ, Yamamoto M, Bernard JP, Deprest J, et al. Prevalence and management of late fetal complications following successful selective laser coagulation of chorionic plate anastomoses in twin-to-twin transfusion syndrome. Am J Obstet Gynecol 2006;194:796-803.

7) Habli H, Bombrys A, Lewis D, Lim F, Polzin W, Maxwell R, et al. Incidence of complications in twin-twin transfusion syndrome after selective fetoscopic laser photocoagulation: a single-center experience. Am J Obstet Gynecol 2009;201:417. e1-7.

8) Lopriore E, Deprest J, Slaghekke F, Oepkes D, Middeldorp JM, Vandenbussche FP, et al. Placental characteristics in monochorionic twins with and without twin anemia-polycythemia sequence. Obstet Gynecol 2008;112:753-8.

9) Lopriore E, van den Wijngaard JP, Middeldorp JM, Oepkes D, Walther FJ, van Gemert MJ, et al. Assessment of feto-fetal transfusion flow through placental arterio-venous anastomoses in a unique case of twin-to-twin transfusion syndrome. Placenta 2007;28:209-11.
10) van Meir H, Slaghekke F, Lopriore E, van Wijngaarden WJ. Arterio-arterial anastomoses do not prevent the development of twin anemia-polycythemia sequence. Placenta 2010;31: 163-5.

11) Slaghekke F, Kist WJ, Oepkes D, Middeldrop JM, Klumper FJ, Vandenbussche FP, et al. TAPS and TOPS: two distinct forms of feto-fetal transfusion in monochorionic twins. Z geburtshilfe Neonatol 2009;213:248-54.

12) Slaghekke F, Kist WJ, Oepkes D, Pasman SA, Middelsorp JM, Klumper FJ, et al. Twin anemia-polycythemia sequence: diagnostic criteria, classification, perinatal management and outcome. Fetal Diagn Ther 2010;27:181-90.

13) Teixeira JM, Duncan K, Letsky E, Fisk NM. Middle cerebral artery peak systolic velocity in the prediction of fetal anemia. Ultrasound Obstet Gynecol 2000;15:205-8.

14) Khalil A, Rodgers M, Baschat A, Bhide A, Gratacos E, Hecher $\mathrm{K}$, et al. ISUOG Practice Guidelines: role of ultrasound in twin pregnancy. Ultrasound Obstet Gynecol 2016;47:247-63.

15) Herway C, Johnson A, Moise K, Moise KJ Jr. Fetal intraperitoneal transfusion for iatrogenic twin anemia-polycythemia sequence after laser therapy. Ultrasound Obstet Gynecol 2009; 33:592-4.

16) Lopriore E, Ortibus E, Acosta-Rojas R, Le Cessie S, Middeldorp JM, Oepkes D, et al. Risk factors for neurodevelopment impairment in twin-twin transfusion syndrome treated with fetoscopic laser surgery. Obstet Gynecol 2009;113:361-6. 